Jurnal Ilmiah Sport Coaching and Education Vol. 3 Juli 2019

\title{
PEMAHAMAN PELATIH FUTSAL LIGA AAFI U16 PADA PERATURAN PERTANDINGAN SESUAI MANUAL LIGA
}

\author{
Ahmad Hasbullah Amza \\ Nur Fitranto \\ Fakultas Ilmu Olahraga Universitas Negeri Jakarta \\ Email : ahmadhasbullahamza@yahoo.com \\ nurfitranto@unj.ac.id
}

\begin{abstract}
ABSTRAK
Penelitian ini bertujuan untuk menentukan tingkat pemahaman pelatih Futsal regional Jakarta tentang peraturan pertandingan Futsal di Manual League AAFI U16. Penelitian ini dilakukan melalui pengumpulan data dengan menyebarkan kuesioner selama pertemuan pelatih Futsal akademik yang diadakan pada 13 - 14 Juli 2019. Penelitian ini dikategorikan sebagai penelitian kuantitatif deskriptif, dengan metode survei menggunakan kuesioner sebagai alat. Subjek penelitian ini adalah pelatih Futsal 70 regional AAFA U16 liga Jakarta. Teknik purposive sampling digunakan dalam penelitian ini sebagai metode pengumpulan sampel untuk sebanyak 30 orang yang diwawancarai. Pengumpulan data menggunakan kuesioner tertutup. Hasil analisis data menunjukkan bahwa pengetahuan tentang aturan pertandingan Futsal oleh pelatih liga AAFI U16 regional Jakarta adalah; 26 orang (65\%) memiliki pengetahuan besar dan 14 orang (35\%) memiliki cukup atau cukup menengah.
\end{abstract}

Kata kunci: Pengetahuan tentang Peraturan Pertandingan, Pelatih, Futsal

\section{ABSTRACT}

This research aims to determine the level of understanding of Jakarta's regional Futsal coaches regarding Futsal match regulations in Manual League AAFI U16. This research was done through data collecting by distributing questionaires during the meetings of academic Futsal coaches that were held on 13 - 14 July 2019. This research is categorized as a descriptive quantitative research, with survey method using questionaires as tools. Rthe subject of the research are the Jakarta's regional Futsal 70 coaches of AAFI U16 league. Purposive sampling technique was used in this research as sample collecting method to as many as 30 interviewees. Data collection using closed questionaires. The data analysis result shown that the knowledge regarding rules of Futsal match by the Jakarta's regional AAFI U16 league coaches are; 26 people (65\%) possesses great knowledge and 14 people (35\%) possesses sufficient or enough intermediate.

Keywords: Knowledge of Match Rules, Coaches, Futsal

\section{PENDAHULUAN}

Olahraga merupakan bagian yang takakan terpisahkan dari kehidupan manusia siapapun, dimanapun dan kapanpun. Olahraga adalah sarana pemersatu bangsa, tidak mengenal perbedaan adat, budaya, ras maupun agama. Olahraga adalah suatu kegiatan yang mempunyai tujuan antara lain memperoleh kesehatan, kesenangan, kesegaran jasmani dan juga dapat bertujuan untuk memperoleh prestasi dalam pelaksanaannya. Semakin beragam jenis 
cabang olahraga, semakin mudah seseorang dalam memilih mana yang disenangi atau disukai dan mana yang bisa di jadikan prestasi atau profesi. Salah satunya yaitu olahraga baru di Indonesia yang dimainkan disetiap event dan sedang booming saat ini adalah olahraga futsal. Futsal adalah salah satu permainan sepak bola mini yang dimainkan didalam ruangan karena ukurannya lebih kecil dari lapangan sepakbola.

Futsal pertama kali dimainkan di Uruguay pada tahun 1930, ketika Versi "Five-To-Five" pada sepak bola ruangan untuk kompetisi pemain muda. Futsal adalah terminology Internasional untuk permainan, sebuah kombinasi perpaduan dari bahasa Spanyol yaitu "Soccer", untuk kata FUTbol dan bahasa Prancis untuk kata "indoor," Untuk SALon. Futsal cepat popiler di Amerika Selatan, khususnya di Brazil.

Dalam futsal, peran pelatih hanya sebagai fasilitator. Pelatih mempersiapkan pertandingan dan materi latihan serta mengevaluasi perkembangan skill, teknik, dan performa pemain. Untuk menangani pemain usia remaja dan kanak-kanak, lebih diutamakan pada pengembangan skill. Ini sesuai dengan karakter anak-anak yang selalu ingin mencoba sesuatu yang baru.

Pengetahuan menjadi sebuah hal yang luar biasa dalam peradaban manusia, karena melalui pengetahuanlah aspek-aspek dalam peradaban manusia berkembang yang kemudian seluruhnya dapat dibedakan berdasarkan ontologi, epistemologi dan aksiologinya. Ontologi membicarakan hakikat (segala sesuatu), ini berupa pengetahuan tentang hakikat segala sesuatu. Epistimologi membicarakan cara memperoleh pengetahuan itu. Dan Aksiologi membicarakan guna pengetahuan itu.

Harsono, "pelatih adalah senantiasa seorang pendidik, seorang guru, akan tetapi seorang guru belum tentu selalu seorang pelatih. Seorang pelatih mencerminkan manusia bagaimana yang tumbuh danberkembang dibawah asuhannya" Artinya seorang hasil yang diperoleh oleh anak asuh merupakan cerminan orang yang melihatnya. Setiap perkembangan dan kemajuan atau kemunduran hasil yang diperoleh tergantung polesan pelatih.

Dalam hal ini pelatih benar-benar menyiapkan dan menciptakan lingkungan latihan sebaik mungkin, seperti :

1. Menyediakan sarana dan prasarana yang memadai

2. Tempat latihan aman, nyaman, dan menyenangkan

3. Pandai memberikan motivasi kepada atlet

4. Tingkah laku simpatik dan energik

5. Mengatur formasi latihan yang baik dan menyenangkan

6. Memilih metode yang tepat

7. Menyajikan variasi bahan latihan

pelatih harus memiliki kemampuan dalam sebuah tim menjadi berhasil dengan gaya kepemimpinan yang dimilikinya dan sudah tentu seorang pelatih harus memiliki informasi yang cukup mengenai hal yang baru dalam bidang yang dipahami sehingga dapat meningkatkan kemampuan pelatih sendiri dalam mengembangkan kemampuan yang telah dimiliknya karena kompetensi sering disamakan dengan keahlian atau kemampuan seseorang yang dapat dilihat oleh orang banyak.

\section{Manual Liga AAFI}

\section{Peraturan Umum}

Maksud dan tujuan buku manual liga ini diterbitkan dengan tujuan untuk menyamakan metode pelaksanaan dan pertandingan dalam kerangka pembinaan futsal usia dini di Liga Wilayah AAFI dan Grand Champion AAFI. Buku manual liga ini sebagai pedoman pihak penyelenggara Wilayah ataupun anggota AAFI selaku peserta liga sehingga harmonisasi penyelenggaraan liga menjadi lebih baik serta memberikan wadah liga yang sesuai demi kemajuan atlet futsal usia dini agar kedepan menjadi atlet futsal nasional yang handal.

Nama Event Liga AAFI Wilayah musim terkait nanti. Penyelenggara dengan sponsor atau pendukung penyelenggara boleh atau bisa menjadikan Liga AAFI 2018 - 2019 Piala pemerintah setempat dan piala sesuai 
sponsor, dengan memberikan hak penuh kepada penyelenggara wilayah untuk penamaan piala Liga AAFI. Event ini adalah pertandingan futsal antar Akademi Futsal yang memiliki pemain dalam rentang usia 9 16 Tahun dengan kelompok yang dipertandingkan : Usia 9-10 Tahun (Tidak Ada Grand Champion), Kelompok Usia 11 13 Tahun Dan Kelompok Usia 14 - 16 Tahun.

2. Penyelenggaraan Liga Wilayah AAFI dan Grandchampion Liga AAFI

Penyelenggara Liga Wilayah AAFI adalah penyelenggara yang ditunjuk langsung oleh pengurus AAFI berdasarkan Memory Of Understanding (MOU) bersama antara penyelenggara beserta dengan pengurus AAFI dan manager atau pelatih peserta liga di wilayah regional terkait. Penyelenggara Wilayah yang Independen bekerja sesuai Manual Liga dan mempunyai hak Penuh mencari Sponsor dan kepentingan Liga lainnya sehingga terlaksana liga tersebut. Keuntungan dan Kerugian pelaksanaan Liga AAFI nantinya adalah sepenuhnya tanggung jawab penyelenggara. Termasuk surat ijin keramaian maupun medis pertolongan pertama, panitia, (kelayakan event adalah tanggung jawab penyelenggara sepenuhnya) Penyelenggara wajib memberi surat kepemilikan lapangan atau surat kerjasama dengan lapangan yang menyatakan bahwa lapangan tersebut dijadikan tempat pelaksanaan Liga AAFI wilayah sampai akhir Liga pada saat Technical Meeting (TM). Manual Liga AAFI sebagai pedoman peserta dalam mengikuti Liga AAFI.

Waktu pelakasanaan liga AAFI diselenggarakan pada bulan Oktober setiap tahunnya dan sampai dengan waktu terjadwal yang telah ditentukan. Penyelenggaraan Grand Champion Liga AAFI akan dikelola langsung oleh AAFI bekerjasama dengan penyelenggara AAFI wilayah tempat berlangsungnya Grand Champion Liga AAFI atau dilakukan oleh puhak ke dua (EO atau Pemilik Lapangan). Penentuan tempat pelaksaanan Babak Grand Champion Liga AAFI akan ditetapkan berdasarkan surat ketetapan hasil rapat pengurus AAFI dan pengurus wilayah.

3. Peserta

Peserta Liga adalah Akademi Futsal yang merupakan Anggota Akademi AAFI. Calon peserta Liga bisa mendaftar di liga wilayah lain diluar domisili akademi calon peserta. Peserta adalah pemain yang berusia 9 - 16 tahun berdasarkan tahun kelahiran. Pemain tidak diperkenankan memperkuat 2 klub di wilayah yang sama ataupun di wilayah yang berbeda. Bila pemain terbukti melakukan pelanggaran, maka pemain akan di kenakan sangsi oleh pihak penyelenggara / pengurus Liga sesuai kesepakatan. Akademi yang telah berpartisipasi mengikuti Liga AAFI selama 3 tahun akan mendapatkan Reward Certificate dari AAFI.

4. Persyaratan Pemain

Setiap pemain yang boleh bermain harus sudah melalui proses Screening yang dilakukan oleh Panitia penyelenggara Liga AAFI wilayah. Adapun syarat proses Screening harus memperlihatkan : Akte Kelahiran Asli (Wajib), NISN (Wajib), Kartu Keluarga (Wajib), Ijazah Asli (Wajib), Raport (Optional), Pas Photo 3 X 4 (Berwarna) 3 Lembar. Dengan batasan Usia 16 Tahun, Usia 13 Tahun, Usia 10 Tahun. Serta senghadirkan calon pemain dan data tersebut akan diperiksa oleh petugas Screening kemudian akan ditentukan layak atau tidaknya calon pemain tersebut.

5. Pendaftaran Tim dan official

Akademi yang ikut Liga AAFI mengisi formulir pendaftaran dengan melengkapi kelengkapan : Data tim, nama tim, logo tim, home base, profil singkat, warna kostum kandang dan tandang

6. Biaya Pendaftaran

Biaya pendaftaran Liga AAFI Maksimal sebesar Rp. 2.000.000,- (Dua Juta Rupiah) / Musim, yang harus dibayarkan lunas sebelum pertandingan liga dimulai.

7. Liga Wilayah AAFI

Setiap tim akan mengikuti babak Liga wilayah AAFI dengan sistem kompetisi penuh pada tiap wilayahnya. Dengan syarat penyelenggara mengadakan Liga wilayah 
memiliki minimal 6 akademi dan maksimal 12 akademi. Apabila peserta lebih dari 12 akademi maka disetiap wilayah boleh menggunakan sistem dua grup.

Sistem pertandingan babak wilayah menggunakan sistem putaran penuh kompetisi (Kandang - Tandang), sistem kandang - tandang dapat menggunakan satu lapangan yang sama. Peringkat terbaik ditentukan berdasarkan poin yang dikumpulkan. Wilayah yang menggunakan sistem dua grup, untuk menentukan juara wilayah ditentukan dengan babak Final Four (Juara grup dan runner up setiap grup). Ketentuan ini berlaku untuk semua kelompok usia

\section{Peraturan Line Up dan Sangsi WO}

Setiap tim wajib memainkan seluruh pemain yang terdaftar di Line $U p$ pada setiap pertandingan. Daftar Line Up setiap akademi minimal 7 pemain dan maksimal 14 pemain. Peserta akan di kenakan sangsi apabila memainkan pemain yang tidak terdaftar di Line Up, akademi di nyatakan kalah Walk Out (WO). Dan apabila jadwal pertandingan sudah mulai dan peserta tidak hadir maka akademi tersebut di nyatakan kalah walk out (WO), sangsi : kalah 3 poin dan 3 gol.

Semua pemain wajib di beri kesempatan bermain minimal 2 Menit (terakumulasi selama pertandingan) pada setiap pertandingan. Sangsiakan diberikan kepada pelatih yang tidak memainkan semua pemain yang terdaftar dalam susunan pemain/line up dan dilarang mendampingi akademi sebanyak sekali pertandingan. Sebelum bertanding pemain dan offisial tim wajib menunjukkan kartu identitas kepada pengawas pertandingan.

Setiap tim mendaftarkan pemain sesuai kuota yaitu 20 pemain per akademi. Dengan pergantian/perpindahan pemain hanya dapat dilakukan pada saat putaran kedua Liga wilayah AAFI. Jumlah pergantian/perpindahan pemain sebanyak 5 pemain. Perpindahan/pergantian pemain antar akademi pada saat kompetisi berjalan melalui prosedur yang ditetapkan oleh panitia menggunakan surat permohonan perpindahan pemain yang dilakukan disetujui oleh kedua belah pihak akademi. Pemain yang sudah bermain full kompetisi di wilayahnya tidak dapat mengikuti pertandingan di wilayah lain ketika masuk putaran kedua. Dan Transfer pemain hanya diperbolehkan untuk di regional setempat, tidak dapat Transfer pemain dari akademi di wilayah lain.

9. Penentuan Klasemen dan Poin

Akademi yang menang mendapatkan 3 Poin dan kalah 0, bila terjadi draw atau seri maka akan diadakan adu Penalty dengan ketentuan penendang penalty sebanyak 5 pemain dan bila terjadi draw kembali maka akan dilakukan pengundian koin. Tim yang seri lalu menang Penalty mendapatkan 2 poin, sedangkan yang seri lalu kalah Penalty mendapatkan 1 poin.

10. Pakaian dan Atribut

Setiap tim wajib memiliki 2 kostum berwarna gelap dan terang (Home \& Away). Setiap pemain wajib menggunakan nomor punggung yang sama hingga Liga Berakhir. Warna kostum penjaga gawang harus berbeda dengan kostum pemain. Dan apabila tim yang menggunakan pemain "Power Play" wajib menggunakan kostum dengan warna yang sama dengan penjaga gawang dan memakai nomor punggung yang sama. Bagi tim yang menggunakan pemain "Power Play" wajib memberikan informasi berapa jumlah pemain dan nomor punggung pemain tersebut. Pada babak Liga wilayah maupun Grand Champion, nama pemain dipunggung jersey tim tidak diwajibkan. Setiap tim yang berlaga wajib menempel Emblem Logo Akademi di dada sebelah kiri dan Emblem Logo AAFI di lengan sebelah kanan.

11. Waktu Permainan

Waktu permainan kategori Usia 9 13 Tahun, menggunakan waktu 2 X 15 menit kotor. Sedangkan kategori Usia $14-16$ Tahun, menggunakan waktu 2 X 20 menit kotor.

\section{Etika Protes}

Protes hanya dapat dilakukan oleh kapten dari masing-masing tim akademi tanpa campur tangan pemain lain disaat pertandingan berjalan dalam lapangan. Protes 
yang berlebihan oleh salah satu akademi pada saat pertandingan, Wasit punya wewenang penuh untuk memberi hukuman. Protes dapat dilakukan akademi secara tertulis/lisan apabila ada ketidakpuasan pada saat pertandingan. Protes secara tertulis/lisan dapat dilakukan sebelum atau sesudah pertandingan Wasit maupun penyelenggara yang telah berdiskusi berhak untuk mendiskualifikasi apabila ada akademi yang tidak sopan dalam bentuk apapun kepada perangkat pertandingan maupun kepada penyelenggara.

13. Etika Tim Kandang dan Tandang

Akademi yang di sebut pertama dalam jadwal pertandingan berlaku sebagai tuan rumah. Tim tamu berada di sebalah kanan pengawas pertandingan. Jika terjadi kesamaan seragam maka tim yang harus mengganti kostum adalah tim tamu. Dan seluruh anggota tim diwajibkan saling bersalaman sebelum dan sesudah pertandingan. Setiap akademi yang bertanding wajib membersihkan area tempat pemain cadangan saat sebelum perpindahan tempat maupun saat meninggalkan lokasi pertandingan

14. Penghargaan dan Sertifikat

Berdasarkan Peraturan FIFA

Grassroot : No Medals \& No Money. Penghargaan pada babak Liga Wilayah :

- 1 st Champion : 15 Bola Futsal + 18 Jersey Player +1 Lusin Rompi Latihan + Cones +2 Jersey Goal Keeper + Piala

- 2 nd Runner Up : 10 Bola Futsal + Cones +18 Jersey Player +2 Jersey GoalKeeper + Piala.

- 3 rd Place : 10 Bola Futsal + Cones +1 Lusin Rompi Latihan + Piala.

Penghargaan pada putaran Grand Champion akan ditentukan dalam Rules \& Regulation tersendiri. Semua penghargaan pada liga AAFI Musim permusimnya merupakan tanggung jawab penyelenggara liga. Sertifikat keikutsertaan diberikan ke seluruh anggota peserta (Pemain, Offisial dan Tim) yang di design oleh AAFI wilayah, ditanda tangani oleh Ketua AAFI wilayah dan diterbitkan oleh penyelenggara wilayah. Sertifikat penghargaan diberikan kepada peringkat 1,2 dan 3 .

Peraturan pertandingan dalam Manual Liga AAFI yang sudah peneliti jelaskan diatas merupakan peraturan pertandingan yang berbeda dengan peraturan pertandingan FIFA dan dengan peraturan Liga Profesional Indonesa. Peraturan pertandingan mengenai Line $U p$ pemain, sangsi $\mathrm{WO}$, dan penentuan poin merupakan peraturan pertandingan yang masih banyak pelatih kurang mengerti tentang ini.

\section{METODE PENELITIAN}

Penelitian ini termasuk penelitian deskriptif kuantitatif dengan metode survei dengan menggunakan angket. Populasi dalam penelitian ini adalah pelatih futsal liga AAFI U16 yang ada di DKI Jakarta. Pelatih Liga futsal AAFI U16 di DKI Jakarta berjumlah 70. Sampel pada penelitian ini adalah pelatih Liga AAFI U16 yang ada di DKI Jakarta berjumlah 40 orang. Teknik pengambilan sampel dalam penelitian ini menggunakan purposive sampling yaitu teknik penentuan sampel dengan pertimbangan tertentu. Pertimbangan tertentu yang dimaksudkan peneliti yakni pertimbangan pelatih futsal liga AAFI U16 jumlahnya 70, lebih banyak dari jumlah pelatih yang belum berlisensi. Kurang nya pelatihan lisensi dan sosialisasi peraturan pertandingan membuat para pelatih tidak berkembang.

Sampel pada penelitian ini adalah pelatih Liga AAFI U16 yang ada di DKI Jakarta berjumlah 40 orang. Teknik pengambilan sampel dalam penelitian ini menggunakan purposive sampling yaitu teknik penentuan sampel dengan pertimbangan tertentu. Pertimbangan tertentu yang dimaksudkan peneliti yakni pertimbangan pelatih futsal liga AAFI U16 jumlahnya 70 , lebih banyak dari jumlah pelatih yang belum berlisensi. Kurang nya pelatihan lisensi dan sosialisasi peraturan pertandingan membuat para pelatih tidak berkembang. Penelitian akan mengunakan 
angket tertutup dalam penelitian ini. Angket tertutup adalah angket yang sudah disajikan sedemikian rupa, dimana pilihan jawabannya telah disediakan, sehingga responden hanya tinggal memilih dan memberikan tanda centang (V) pada jawaban atau peryataan yang sesuai dengan pendapat atau pengetahuan responden. Sebelum membuat pernyataan angket, terlebih dahulu dibuat kisi-kisi peryataan. Adapun angket yang digunakan nanti adalah angket yang dibuat sendiri oleh peneliti. Angket ini mengungkap tentang tingkat pengetahuan pelatih terhadap peraturan pertandingan yg sesuai dengan manual Liga AAFI yang terdiri dari 30 butir soal dengan pernyataan.

Tabel Kisi-kisi Soal Pengetahuan Peraturan Pertandingan Futsal Liga AAFI

\begin{tabular}{|c|c|c|}
\hline Faktor & $\begin{array}{c}\text { Indikato } \\
\mathbf{r}\end{array}$ & $\begin{array}{c}\text { No. } \\
\text { Buti } \\
\text { r } \\
\text { Soal } \\
\end{array}$ \\
\hline $\begin{array}{l}\text { Pengetahuan } \\
\text { Liga AAFI }\end{array}$ & $\begin{array}{l}\text { Mengetahui } \\
\text { dan memahami } \\
\text { apa itu AAFI }\end{array}$ & $\begin{array}{l}1,2, \\
3\end{array}$ \\
\hline $\begin{array}{l}\text { Persyaratan } \\
\text { pemain }\end{array}$ & $\begin{array}{l}\text { Mengetahui apa } \\
\text { saja persyaratan } \\
\text { pemain }\end{array}$ & 4,5 \\
\hline $\begin{array}{l}\text { Persyaratan } \\
\text { Pendaftaran } \\
\text { Tim }\end{array}$ & $\begin{array}{l}\text { Mengetahui } \\
\text { biaya } \\
\text { pendaftaran dan } \\
\text { perlengkapan } \\
\text { pendaftaran }\end{array}$ & 6,7 \\
\hline $\begin{array}{l}\text { Line } \quad U p \\
\text { pemain }\end{array}$ & $\begin{array}{l}\text { Mengetahui } \\
\text { peraturan Line } \\
U p \text { pemain }\end{array}$ & $\begin{array}{l}8,9, \\
10\end{array}$ \\
\hline $\begin{array}{l}\text { Sangsi } \text { WO } \\
\text { dan Line } U p\end{array}$ & \begin{tabular}{l}
\multicolumn{2}{l}{ Memahami } \\
aturan sangsi \\
apabila \\
Walking Out \\
(WO) dan Line \\
$U p$
\end{tabular} & $\begin{array}{l}11 \\
12 \\
13\end{array}$ \\
\hline
\end{tabular}

\begin{tabular}{|c|c|c|}
\hline $\begin{array}{l}\text { Perpindahan } \\
\text { dan Transfer } \\
\text { pemain }\end{array}$ & $\begin{array}{l}\text { Mengetahui } \\
\text { cara } \\
\text { Memahamin } \\
\text { aturan } \\
\text { perpindahan } \\
\text { pemain }\end{array}$ & $\begin{array}{l}14 \\
15 \\
16\end{array}$ \\
\hline $\begin{array}{l}\text { Penghitunga } \\
\mathrm{n} \text { poin }\end{array}$ & $\begin{array}{l}\text { Mengetahui } \\
\text { cara } \\
\text { penghitungan } \\
\text { poin }\end{array}$ & $\begin{array}{l}17 \\
18\end{array}$ \\
\hline $\begin{array}{l}\text { Perhitungan } \\
\text { klasmen }\end{array}$ & $\begin{array}{l}\text { Mengetahui } \\
\text { cara } \\
\text { penghitungan } \\
\text { klasmen }\end{array}$ & 19 \\
\hline $\begin{array}{l}\text { Pakaian dan } \\
\text { atribut }\end{array}$ & $\begin{array}{l}\text { Mengetahui } \\
\text { kelengkapan } \\
\text { atribut } \\
\text { pertandingan }\end{array}$ & $\begin{array}{l}20 \\
21\end{array}$ \\
\hline $\begin{array}{l}\text { Waktu } \\
\text { permainan }\end{array}$ & $\begin{array}{l}\text { Mengetahui } \\
\text { durasi } \\
\text { permainan }\end{array}$ & $\begin{array}{l}22 \\
23\end{array}$ \\
\hline Etikaprotes & $\begin{array}{l}\text { Mengetahui } \\
\text { cara protes saat } \\
\text { pertandingan }\end{array}$ & $\begin{array}{l}24 \\
25\end{array}$ \\
\hline $\begin{array}{ll}\text { Etika } & \text { tim } \\
\text { kandang } & \text { dan } \\
\text { tandang } & \end{array}$ & $\begin{array}{l}\text { Mengetahui } \\
\text { peraturan tim } \\
\text { kandang dan } \\
\text { tandang saat } \\
\text { pertandingan }\end{array}$ & $\begin{array}{l}26 \\
27\end{array}$ \\
\hline $\begin{array}{l}\text { Penghargaan } \\
\text { juara }\end{array}$ & $\begin{array}{l}\text { Mengetahui } \\
\text { penghargaan } \\
\text { juara }\end{array}$ & $\begin{array}{l}28 \\
29 \\
30\end{array}$ \\
\hline
\end{tabular}

Proses pengumpulan data dilakukan dengan cara menyampaikan atau memberikan angket kepada responden yang dalam hal ini adalah pelatih futsal liga AAFI usia 16 tahun di regional DKI Jakarta. Peneliti membagikan angket secara langsung kepada responden. Peneliti terlebih dahulu membagikan soal kepada pelatih dan memberikan waktu 30 menit untuk mengisi soal, total pernyataan kuisioner (angket) sebanyak 30 pernyataan. Sebelum memulai pengerjaan peneliti telah memberikan penjelasan kepada 
responden mengenai tata cara pengisian biodata maupun dalam menjawab butir soal pernyataan. Tahap terakhir peneliti merekap semua data dan mengolahnya.

Data yang diperoleh dalam penelitian ini berupa data kuantitatif, maka setiap jawaban dari data pernyataaan diberi skor, dengan menggunakan skala Guttman. Jika benar mendapat nilai 1 dan jika salah mendapat nilai 0 . Mengacu pada langkah-langkah pengkategorian maka pengkategorian dengan skala tiga dalam penelitian ini adalah sebagai berikut:

Tabel.1. Norma Pengkategorian

\begin{tabular}{lcc}
\hline \multirow{2}{*}{ No } & \multicolumn{1}{c}{ Kategori } & \multicolumn{2}{c}{ Kurva } \\
& Normal & Kategori \\
\hline 1 & {$[\mu+1,0 \sigma] \leq X$} & Tinggi \\
\hline \multirow{2}{*}{2} & {$[\mu-1,0 \sigma] \leq X<[\mu+$} \\
& $1,0 \sigma]$ & Sedang \\
\hline 3 & $X<[\mu-1,0 \sigma]$ & Rendah \\
\hline
\end{tabular}

Keterangan:

$\mu=$ Median

$\sigma=$ Standar Deviasi Ideal

Penyimpulan dimasukkan ke dalam tiga kategori tinggi, sedang, rendah. Pengkategorian didasarkan pada mean ideal $(\mu)$ dan standar deviasi ideal $(\sigma)$. Pengkategorian dengan standar deviasi dan rerata dapat dibagi menjadi lima atau tiga kelas.

\section{HASIL PENELITIAN}

Hasil penelitian ini menunjukkan pengetahuan pelatih futsal Liga AAFI regional DKI Jakarta. Data penelitian berdasarkan pada hasil pengisian angket pengetahuan peraturan pertandingan yang berjumlah 30 butir pernyataan. Analisis data penelitian ini menggunakan teknik statistik deskriptif. Adapun teknik perhitungan pertanyaan tertutup menggunakan persentase, yang dibuat dalam bentuk tiga kategori yaitu: tinggi, sedang, dan rendah. Pengkategorian dibuat berdasarkan mean ideal dan standar deviasi ideal. Hasil perhitungan distribusi frekuensi pengetahuan peraturan pertandingan pelatih liga AAFI regional DKI Jakarta dapat dilihat pada tabel berikut:

Tabel 2. Distribusi Frekuensi Pengetahuan Peraturan Pertandingan Liga AAFI Regional

\begin{tabular}{|c|c|c|c|c|}
\hline \multirow{2}{*}{ No } & \multirow{2}{*}{ Kategori } & \multirow{2}{*}{$\begin{array}{l}\text { Interval } \\
\text { Skor }\end{array}$} & \multicolumn{2}{|c|}{ Frekuensi } \\
\hline & & & $\mathbf{F}(\mathbf{n})$ & $\%$ \\
\hline 1 & Tinggi & $>20$ & 26 & 65 \\
\hline 2 & Sedang & $10-20$ & 14 & 35 \\
\hline 3 & Rendah & $<10$ & 0 & 0 \\
\hline \multicolumn{2}{|c|}{ Total } & & 40 & 100 \\
\hline
\end{tabular}
dari keseluruhan subjek penelitian yang berjumlah 40 orang, sebanyak 14 orang $(35 \%)$ subjek penelitian memiliki pengetahuan yang sedang pada pengetahuan peraturan pertandingan futsal liga AAFI, sedangkan sebanyak 26 orang $(65 \%)$ subjek penelitian lainnya memiliki pengetahuan yang tinggi pada pengetahuan peraturan pertandingan liga AAFI. Berdasarkan hasil analisis data tersebut dapat disimpulkan bahwa pengetahuan peraturan pertandingan pelatih futsal Liga AAFI regional DKI Jakarta termasuk tinggi. Secara visual distribusi persentase dapat dilihat pada histogram berikut :

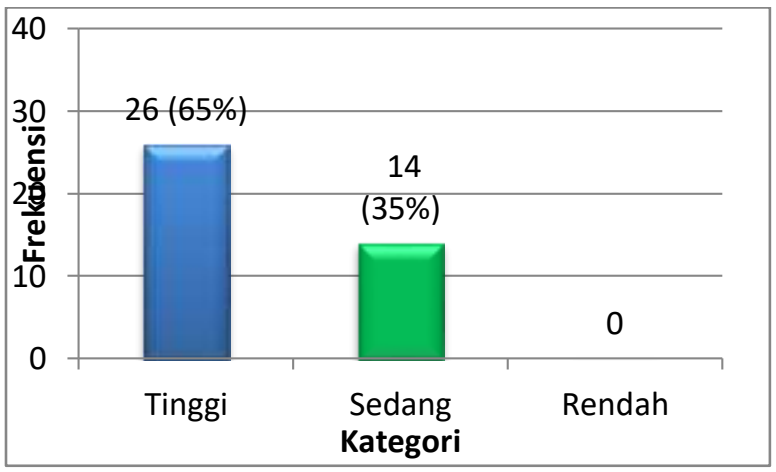

Gambar. 1. Histogram Distribusi Frekuensi Persentase Pengetahuan Peraturan Pertandingan Futsal Pelatih Liga AAFI Regional DKI Jakarta 
Pengetahuan peraturan pertandingan Liga AAFI terdiri dari beberapa faktor, yaitu: 1) Pengetahuan AAFI, 2) Persyaratan Pemain, 3) Persyaratan Pendaftaran Tim, 4) Line Up Pemain, 5) Sangsi WO dan Line Up, 6) Perpindahan dan Transfer Pemain, 7) Perhitungan Poin, 8) Perhitungan Klasmen, 9) Pakaian dan Atribut, 10) Waktu Permainan, 11) Etika Protes, 12) Etika Tim Kandang dan Tandang, 13) Penghargaan Juara. Secara lebih detail dapat diketahui pengetahuan pelatih dari masing-masing faktor tersebut. Berikut deskripsi pengetahuan pelatih berdasarkan dimensi atau aspek pengetahuan peraturan pertandingan Liga AAFI.

\section{KESIMPULAN}

Berdasarkan hasil analisis pada pembahasan dapat disimpulkan secara keseluruhan tingkat pemahaman peraturan pertandingan pelatih futsal Liga AAFI regional DKI Jakarta adalah tinggi atau baik. Dari 40 responden di dapat sebanyak 26 pelatih $(65 \%)$ memiliki tingkat pemahaman yang tinggi atau baik terhadap peraturan pertandingan Manual Liga AAFI, sedangkan 14 pelatih $(35 \%)$ memiliki pengetahuan sedang atau cukup terhadap peraturan pertandingan Manual Liga AAFI. Kemudian dalam hal ini peneliti berharap penelitian ini dapat bermanfaat bagi perkembangan futsal di indonesia khususnya untuk Liga AAFI.

\section{SARAN}

Berdasarkan hasil penelitian ini, terdapat beberapa saran sebagai berikut:

1. Untuk pelatih yang mengikuti Liga AAFI diharapkan menambah pengetahuannya tentang apa itu AAFI, tentang peraturanperaturan di Manual Liga AAFI, menjadi pelatih yang aktif di komunitas AAFI setiap regionalnya, dan mengikuti atau ikut dalam pertemuan untuk membahas soal Liga AAFI yang akan menambah wawasan pengetahuan yang untuk kepentingan dan kemajuan bersama

2. Untuk pengurus AAFI khusus nya pengurus di regional, membuat pertemuan atau sosialisai manual liga AAFI lebih sering lagi, membuat bahan evaluasi dan memberikan kesempatan para pelatih untuk dapat memberikan masukan atau pendapat tentang Liga AAFI. Mengajak pelatih-pelatih yang jarang ikut berkumpul bareng agar tingkat pengetahuan tentang Liga AAFI ini lebih baik lagi.

3. Untuk Federasi Futsal Indonesia (FFI) mendukung dan memperhatikan Liga AAFI ini lebih baik lagi, AAFI sebagai wadah usia dini mengembangkan potensi akan lebih baik lagi jika di dukung dan di perhatikan oleh Federasi FFI atau PSSI

\section{DAFTAR PUSTAKA}

Andri Irawan, Teknik Dasar Modern Futsal, Jakarta : Pena Pundi Aksara, 2009

Harsono, Ilmu Coaching, Jakarta, KONI pusat Januari 1986

Jhon D Tenang, Mahir Bermain Futsal, Bandung: Dar! Mizan, 2008

Jujun Suriasumantri, Filsafat Ilmu Sebagai Sebuah Pengantar Populer Jakarta: Pustaka Sinar Harapan, 2009

Manual Liga AAFI 2018-2019

Ned Mcintosh, Jef Thaler, The Baffled Parents's Guide to Coaching Indoor Youth Soccer, New York; Ragged Moutain Press/Mc Graw Hill, 2004

Sugiyono, Metode Penelitian Kuantitatif,

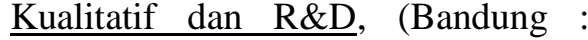
ALFABETA, 2009 